\title{
Characterisation and Application Studies of Sophorolipid Biosurfactant by Candida tropicalis RA1
}

\author{
Rutuja Ankulkar ${ }^{1,2 *}$ (D) and Meera Chavan ${ }^{1}$ if \\ ${ }^{1}$ Department of Microbiology, Walchand College of Arts and Science, Solapur - 413 006, India. ${ }^{2}$ Praj Matrix R\&D \\ Center, Division of Praj Industries Ltd, Pune, 402/403/1098, Urawade, At: Pirangut, Taluka: Mulshi, Pune - 412 \\ 115 , India.
}

\begin{abstract}
The present study reports isolation of Candida tropicalis RA1 from oil contaminated refinery soil. The study depicted production of $\mathbf{3 1} \mathrm{g}$ sophorolipid (SLs) $\mathrm{I}^{-1}$ by Candida tropicalis RA1 until $240 \mathrm{~h}$, using soya oil. Semi-purified SLs had critical micelle concentration of $0.5 \%$, minimum surface tension of $30 \mathrm{mN} \mathrm{m}^{-1}$, oil spreading activity of $32.2 \mathrm{~mm}^{2}$, and emulsification index of $85 \%$ against crude oil. The major SLs forms observed were non-acetylated lactonic and di-acetylated acidic type, with $35.5 \%$ and $32.2 \%$ relative abundance. Semi-purified SLs inhibited human pathogens; Escherichia coli, Listeria monocytogenes and Staphylococcus aureus at 1000, 500, and $250 \mathrm{~g} \mathrm{ml}^{-1}$ minimum inhibitory concentrations (MIC) respectively. In addition, $C$. tropicalis $\mathrm{RA1}$ represented $74 \%$ mercury biosorption at $0.5 \mathrm{mg} \mathrm{l}^{-1}$ concentration, by day 15 . The present study reports establishment of equilibrium phase of lead, cadmium, and mercury at concentrations higher than maximum contaminant levels (MCL) standards. The observations reveal the future potential applications of $C$. tropicalis RA 1 in the industrial, biomedical, and bioremediation fields respectively.
\end{abstract}

Keywords: Antimicrobial properties, Biosurfactant, Biosorption, Candida tropicalis, Heavy metals, Sophorolipid.

*Correspondence: rutuja.govardhan@gmail.com; +91-9960400905

(Received: 02 July 2019; accepted: 13 August 2019)

Citation: Rutuja Ankulkar and Meera Chavan, Characterisation and Application Studies of Sophorolipid Biosurfactant by Candida tropicalis RA1, J Pure Appl Microbiol., 2019; 13(3): 1653-1665. https://doi.org/10.22207/JPAM.13.3.39

(c) The Author(s) 2019. Open Access. This article is distributed under the terms of the Creative Commons Attribution 4.0 International License which permits unrestricted use, sharing, distribution, and reproduction in any medium, provided you give appropriate credit to the original author(s) and the source, provide a link to the Creative Commons license, and indicate if changes were made. 


\section{INTRODUCTION}

Sophorolipids (SLs) are natural surfactants of microbial origin. Covalent bonding between hydrophilic and hydrophobic segments of glycolipid demonstrates low toxicity along with solubilization and emulsification properties. Biosurfactant have sculptured a promising position due to uncommon environmental friendliness. They overcome major drawbacks associated with chemical surfactants. Biosurfactants can be produced from renewable materials. They possess high specificity and remain functional under extreme conditions. In recent times, more attention is being paid to investigate biomedical functionalities of biosurfactant including; antimicrobial, antiviral, and anticancer properties ${ }^{1}$. Also, their ionic nature effectively removes the heavy metals from polluted land sites or aquatic bodies ${ }^{2}$.

Nonetheless, advantages of these bio-molecules contradict with huge costs of manufacturing and recovery. It demands significant enhancement and innovation in order to escalate the commercialization rate of biosurfactant. Also, novel microbial strains and biosurfactants are equally significant to fulfill new challenges.

Sophorolipids are commercial biosurfactant that demonstrates excellent surface activity, and antimicrobial, anticancer, antiviral, and biodegradation properties. Sophorolipid biosurfactant are produced by Candida bombicola, Candida apicola, Candida batistae, Wickerhamiella domercqiae, and Rhodotorula bogoriensis. The most famous, Saccharomyces bombicola ATCC 22214 is reported for high SLs yields using vegetable oils and saccharide substrates. In addition, Rispoli et al. ${ }^{3}$ reported $177 \mathrm{~g} \mathrm{SLS}^{-1}$ by S. bombicola ATCC 22214 using simplex-centroid design studies. The SLs production using feed stocks and microbial strains was also reported by Shao et al. ${ }^{4}$ and Cavalero and Cooper ${ }^{5}$. However, few researches by Chandran and Das ${ }^{6}$, Almeida et al. ${ }^{7}$, and Daylin et al. ${ }^{8}$ state SLs production using C. tropicalis, where diesel oil, oleic acid have been reported substrates. The current research reports SLs production by $C$. tropicalis RA1, isolated from oil contaminated refinery soil. The study investigates SLs characteristics using FT-IR and LC-MS analysis. In addition, antimicrobial and biosorption properties of $C$. tropicalis RA1 are reported.

\section{MATERIALS AND METHODS Isolation of yeast}

Soil samples from oil contaminated refinery area, Pune, Maharashtra, India were used for the isolation of biosurfactant producing microorganisms. Samples were collected in sterile glass tubes. Isolation of yeast was followed according to Gumel et al. ${ }^{9}$ with some modifications. The soil sample $(1 \mathrm{~g})$ was enriched in $100 \mathrm{ml}$ Yeast extract-Peptone-Dextrose broth medium (YPD) containing; Yeast extract, $10 \mathrm{~g}^{-1}$; Peptone, $20 \mathrm{~g}^{-1}$; Dextrose, $20 \mathrm{gl}^{-1}$, and $100 \mathrm{mg} \mathrm{l}^{-1}$ Azithromycin used as antibacterial agent. It was incubated at $30 \pm 2^{\circ} \mathrm{C}$ for $48 \mathrm{~h}$. The grown biomass $(0.1 \mathrm{ml})$ was spread inoculated on YPD agar medium. It was incubated at $30 \pm 2^{\circ} \mathrm{C}$ for $48 \mathrm{~h}$. Isolated colonies were purified on YPD agar medium.

The isolated colonies were evaluated for biosurfactant production using surface tension (ST) reduction, oil displacement, drop collapse, and emulsification index (E24) analysis. The ST reduction was determined using Minimum salt medium (MSM), containing $\mathrm{NaNO}_{3}, 15 \mathrm{~g} \mathrm{I}^{-1} ; \mathrm{KCl}$, $1.1 \mathrm{gl}^{-1} ; \mathrm{NaCl}, 1.1 \mathrm{~g} \mathrm{l}^{-1} ; \mathrm{FeSO}_{4} 0.00028 \mathrm{~g} \mathrm{l}^{-1} \mathrm{KH}_{2} \mathrm{PO}_{4}$ $3 \mathrm{H}_{2} \mathrm{O}, 3.4 \mathrm{~g} \mathrm{l}^{-1} ; \mathrm{K}_{2} \mathrm{HPO}_{4} 4.4 \mathrm{~g} \mathrm{l}^{-1} ; \mathrm{MgSO}_{4}, 0.5 \mathrm{~g} \mathrm{l}^{-1}$; Yeast Extract, $0.5 \mathrm{~g}^{-1}$; ; and $2 \%$ soya oil. Digital tensiometer (Kruss Tensiometer) was used for ST analysis.

\section{Gene}

18S rRNA gene sequencing and phylogenetic analysis

Yeast strain RA1 was selected for $18 \mathrm{~S}$ rRNA gene sequencing. Extraction and purification of DNA was performed using Cetyl trimetyl ammonium bromide (CTAB) and Chloroform/ Isoamyl alcohol $\left(24: 1, v^{-1}\right)^{10}$. The polymerase chain reaction (PCR) was performed using a pair of $18 \mathrm{~S} F$ (GTCAGAGGTGAAATTCTTGG-ATTTA) and 18S R (AGGGCAGGGACGTAA TCAACG) primers. The PCR reaction was performed in $25 \mu$ volume using $1 \mu \mathrm{l}$ of each primer, deoxynucleotide triphosphates (dNTPs, $10 \mathrm{mM}$ each), $0.5 \mu \mathrm{l} \mathrm{Taq}$ DNA polymerase (Takara) supplied with 10x PCR buffer $(5 \mu \mathrm{l})$, and water. The PCR was performed using program : $95^{\circ} \mathrm{C}$ for $5 \mathrm{~min}, 95^{\circ} \mathrm{C}, 1 \mathrm{~min} ; 50^{\circ} \mathrm{C}$, $1 \mathrm{~min} ; 72^{\circ} \mathrm{C}, 2 \mathrm{~min}$, and $72^{\circ} \mathrm{C}$ for $5 \mathrm{~min}$ followed by 30 cycles. The PCR products were purified by QIAquick gel extraction kit (Qiagen, Cat no-28704) and directly sequenced with Big dye terminator V3.1 Cycle sequencing Kit (Applied Biosystems, Cat 
no-4337455). Result of cycle sequencing reaction was observed on Genetic Analyzer computer using sequencing analysis software 5.2 . The similarity of the $18 \mathrm{~S}$ rRNA sequence to the GenBank genomic sequences was investigated using BLASTN software (http://www.blastn.ncbi.nlm.nih.gov). The isolated yeast strain was identified after bioinformatics analysis.

\section{Nucleotide sequence accession number}

Partial 18S rRNA gene sequence of 634 bp obtained in the present study was deposited in the GenBank database (accession number MH161378).

Culture preservation, inoculum preparation, and fermentation

Yeast strain RA1 was preserved in YPD broth medium supplemented with $15 \%\left(\mathrm{~V} \mathrm{v}^{-1}\right)$ glycerol. The strain was archived at $-80^{\circ} \mathrm{C}$. Viability testing was performed after a monthly interval.

For inoculum preparation, one vial of glycerol stock was inoculated in $100 \mathrm{ml}$ YPD broth in $250 \mathrm{ml}$ capacity Erlenmeyer flask and incubated at $30 \pm 2^{\circ} \mathrm{C}$ for $24 \mathrm{~h}$. Inoculum was observed microscopically. Microbial cell count of the inoculum was determined using Neubar Chamber Haemocytometer (Rohem, India). Fermentation studies were performed using 1 liter MSM supplemented with $10 \%$ inoculum and $2 \%$ soya oil, at reaction conditions of $30 \pm 2^{\circ} \mathrm{C}$ until $240 \mathrm{~h}$. The sample was analysed for biomass concentration $(\mathrm{g} / \mathrm{l})$, SLs concentration $(\mathrm{g} / \mathrm{l}), \mathrm{pH}$, and ST after every $24 \mathrm{~h}$.

\section{Biomass determination and biosurfactant extraction}

In the process of biomass determination, $10 \mathrm{ml}$ of whole cell broth was sampled from fermenter at the interval of $24 \mathrm{~h}$. It was centrifuged at $23008 \times \mathrm{g}$ for $15 \mathrm{~min}$. The wet biomass was rinsed three times using distilled water. It was dried in a hot air over at $105^{\circ} \mathrm{C}$ until $24 \mathrm{~h}$, followed by dry weight estimation ${ }^{11}$. SLs were solvent extracted using ethyl acetate as described by Smyth et $a{ }^{12}$. For this, whole cell broth was treated with ethyl acetate $\left(1: 1, \vee v^{-1}\right)$ three times, and pellet containing SLs was removed, washed properly with distilled water.

\section{Purification of biosurfactant}

Sophorolipid purification was performed using silica gel column chromatography ${ }^{12}$. The method was modified in which the column (24'
$3.0 \mathrm{~cm}^{2}$ ) was packed with silica gel slurry (mesh size 60-120 mm) mixed with chloroform. Before loading to the column, crude SLs (1g) extract was dissolved in $10 \mathrm{ml}$ chloroform. Gradient system of chloroform: methanol $(0 \%-50 \%)$ was used for the elution of samples. Elutes were collected and vacuum dried at $50^{\circ} \mathrm{C}$. The samples were stored at $-20^{\circ} \mathrm{C}$ till further usage.

\section{Biosurfactant characterisation}

Surface tension and critical micelle concentration were determined to characterise the biosurfactant produced by strain RA1. Fermented broth of strain RA1 was used for evaluation; every $24 \mathrm{~h}$, until $240 \mathrm{~h}$. The surface tension was measured using tensiometer at $25^{\circ} \mathrm{C}$ with pendant drop method. Tensiometer was calibrated using distilled water (ST $72.5 \mathrm{mN}$ $\mathrm{m}^{-1}$ ) to have definite analysis. Critical micelle concentration was obtained using Rufino et al. ${ }^{13}$ method. For this, semi-purified SLs was used in the range of $10 \mathrm{mg} \mathrm{l}^{-1}$ to $300 \mathrm{mg} \mathrm{l}^{-1}$.

\section{Emulsification index analysis}

Emulsification index was determined using Cooper and Goldenberg ${ }^{14}$ method, It was modified wherein; oil substrate and cell-free broth were mixed in the test tube $\left(1: 1, v^{-1}\right)$; vortexed for $120 \mathrm{~s}$. The mixture was left until $24 \mathrm{~h}$. Emulsification index was calculated using following equation.

$$
\mathrm{E} 24=\frac{\mathrm{He}}{\mathrm{Ht}} \times 100
$$

Where, E24= Emulsification index, $\mathrm{He}=$ Height of the emulsion layer and $\mathrm{Ht}=$ Height of total mixture.

\section{Stability determination}

The cell free broth was used to determine the stability of SLs biosurfactant. The ST reduction was examined for $\mathrm{pH}$, temperature, and salinity parameters. The $\mathrm{pH}$ stability was examined using $\mathrm{pH}$ range of 2.0-10.0. The values were adjusted using $50 \% \mathrm{NaOH}$ or $50 \% \mathrm{HCl}$. The thermal stability was analysed at temperature range of $20^{\circ} \mathrm{C}$ to $121^{\circ} \mathrm{C}$. The salinity was determined using $5 \%-20 \%$ $\mathrm{NaCl}\left(\mathrm{w} \mathrm{v}^{-1}\right)$.

\section{Compositional analysis of biosurfactant \\ Thin layer chromatography}

Thin layer chromatography (TLC) was performed using solvent extracted SLs. For this, $10 \mu \mathrm{l}$ of the phase separated semi-purified SLs was applied over thin layer chromatography on pre-coated silica gel of standard $20 \times 20$ Kiesel- 
gel $60 \mathrm{~F} 254$ Merck plates using solvent system of Chloroform / Methanol / Water (6.5:1.5:0.2, v $\left.\mathrm{V}^{-1}\right)^{12}$. P-anisaldehyde was used for visualization purpose.

Fourier transformation infrared spectroscopy Semi-purified SLs was used for Fourier transformation infrared spectroscopy (FT-IR) analysis. The FT-IR spectra were reported using Perkin-Elmer 31725 X FT-IR spectrophotometer in a spectral region of $4000-400 \mathrm{~cm}^{-1}$, where potassium bromide $(\mathrm{KBr})$ solid cells were used. Spectra were recorded and analysed using standard method ${ }^{15}$.

Liquid chromatography-mass spectrometry analysis

Mass spectra of SLs were reported on MS system. It consists of an HPLC (Agilent 1200 Series, Agilent Technologies) and 6210 Time-of-Flight LC-MS (Agilent Technologies). Zorbax Eclipse Plus C18 column and a DAD detector were used for recording purpose. The mobile phase contained solvent A $(0.2 \%$ formic acid in water) and B (acetonitrile) in a gradient mode: 0-1.5 min 95\% A, 1.5-12 min 95-5\% A, 12-15 min 5\% A, 15-16 $\min 5-95 \% A^{16}$.

\section{Antibacterial activity}

The antibacterial activity of SLs was studied against human pathogens; Escherichia coli (ATCC 35218), Listeria monocytogenes (ATCC 19215) and Staphylococcus aureus (NCIM 5345, NCIM 2079) using micro-broth dilution technique. It was performed using two fold serial dilutions in a 96-well flat bottom microtiter plate ${ }^{10}$. The assay was interpreted using minimum inhibitory concentration (MIC). It is described as the lowest concentration at which; no growth is recorded.

\section{Heavy metal ions biosorption}

\section{Yeast biomass preparation for biosorption}

The yeast strain, $C$. tropicalis RA1 was inoculated in $100 \mathrm{ml}$ YPD broth ( $\mathrm{pH} \mathrm{7.0)}$ and incubated at $30^{\circ} \mathrm{C} \pm 2^{\circ} \mathrm{C}$ for $24 \mathrm{~h}$. The cell biomass was harvested by centrifugation (Eppendorf, 5810 R) at $6603 \times \mathrm{g}$ for $30 \mathrm{~min}$. The biomass was washed thrice with sterile water followed by freeze-drying using lyophilizer (Heto Powder Dry LL 3000).

\section{Biosorption experiment}

Freeze-dried cells $(0.5 \mathrm{~g})$ were inoculated to a series of $500 \mathrm{ml}$ Erlenmeyer flasks (Three flasks for each metal) containing $200 \mathrm{ml}$ diluted solution of $0.1 \mathrm{mg} \mathrm{l}^{-1}, 0.5 \mathrm{mg} \mathrm{l}^{-1}$, and $1.0 \mathrm{mg} \mathrm{l}^{-1}$ arsenic, lead, cadmium, mercury, chromium, and nickel. It was added independently in three sets for each different concentration studied. The concentrations of heavy metals were finalized on the basis of maximum contaminant levels ( $\mathrm{MCL}$ ) standards ${ }^{17}$. Initial $\mathrm{pH}$ of the broth was adjusted to 7.0. It was incubated at $30^{\circ} \mathrm{C}$ for $16 \mathrm{~d}$. Cell broth ( $5 \mathrm{ml}$ ) was collected on d0, d5, d10, and d15 intervals. It was filtered using $0.2 \mu \mathrm{m}$ membranes. The supernatant was analysed for metal ions, using Inductively Coupled Plasma Mass Spectrometry (ICP-MS, Perkin Elmer Optima 2100 DV). The biosorption experiments were run in triplicates. Also, blank experiments were conducted to ensure that no adsorption had taken place on the experimental apparatus used (data not shown). The heavy metal removal was calculated according to Ibrahim et al. ${ }^{18}$.

$$
\text { Metal removal }(\%)=100 \times \quad \frac{\mathrm{C} 0-\mathrm{Ce}}{\mathrm{Ce}}
$$

Where, $\mathrm{C}_{0}$ is the initial metal ions concentration ( $\mathrm{mg} \mathrm{l}^{-1}$ ) and $\mathrm{C}_{e}$ is the equilibrium concentration of metal ions $\left(\mathrm{mg} \mathrm{l}^{-1}\right)$.

\section{Statistical analysis}

The experiments were performed in triplicates. The standard deviation (SD) was represented by error bars in the graphs. The significant differences between fermentation time (h) and SLs yield $\left(\mathrm{g} \mathrm{l}^{-1}\right.$ ) was calculated using simple linear regression where response of SLs yield ( $g$ $\mathrm{I}^{-1}$ ) was determined against independent variable of fermentation time (h). Differences between means were considered significant at a $P$ value of 0.05 . Whereas, significant differences between yeast biomass and heavy metal biosorption was analysed using multivariate analysis of variance (MANOVA) at $\mathrm{Cl}$ of $95 \%$. Statistical analysis was performed using the Minitab ${ }^{\circledR}$ 17.1.0.

\section{RESULTS}

Isolation of yeast

Morphologically twelve different yeasts were isolated from oil contaminated refinery soil. Among all, strain RA1 exhibited promising activities in primary screening. The strain displayed positive results in drop collapse with $85 \%$ E24 against crude oil. Oil displacement denoted an area of $32.2 \mathrm{~mm}^{2}$, along with decrease in ST (from 68.8 $\mathrm{mN} \mathrm{m}{ }^{-1}$ to $29.9 \mathrm{mN} \mathrm{m}^{-1}$ ) was observed. The $18 \mathrm{~S}$ rRNA gene sequencing of strain RA1 generated a 
contig sequence of $634 \mathrm{bp}$. NCBI BLAST analysis of strain RA1 revealed $99 \%$ similarity with $C$. tropicalis KY118179.1 and KU341838.1 respectively. Based on the results, strain RA1 was identified as $C$. tropicalis (Fig. 1a-1b).

\section{Biosurfactant production and kinetics}

The growth characteristic feature and SLs production by $C$. tropicalis RA1 are presented in Fig. 2. Current research reports a short lag phase while yeast growth. The strain displayed exponential phase until $144 \mathrm{~h}$. During this period, $35 \mathrm{~g} \mathrm{l}^{-1}$ biomass and $1.7 \times 10^{10}$ colony forming units
(CFU) $\mathrm{ml}^{-1}$ were observed. The stationary phase represented $36 \mathrm{~g} \mathrm{l}^{-1}$ cell biomass, after $216 \mathrm{~h}$ of growth. Reduction in biosurfactant yield from $32 \mathrm{~g} \mathrm{l}^{-1}$ to $22 \mathrm{~g} \mathrm{l}^{-1}$ after $240 \mathrm{~h}$, was statistically significant $(P<0.01)$. The present study reports $3.21 \times 10^{10} \mathrm{CFU} \mathrm{ml}{ }^{-1}$ after $72 \mathrm{~h}$ wherein ST reduction observed from $68 \mathrm{mN} \mathrm{m}^{-1}$ to $29.9 \mathrm{mN} \mathrm{m}^{-1}$ remained stable until $240 \mathrm{~h}$. No significant change in the $\mathrm{pH}$ was observed during the experiment. The present research exemplifies $35 \mathrm{~g} \mathrm{SLs} \mathrm{I}^{-1}$ yield by C. tropicalis RA1 using $2 \%$ soya oil.

a

\begin{tabular}{|c|c|c|c|c|c|c|c|c|c|}
\hline Sample & $\begin{array}{c}\text { Gene bank } \\
\text { entry }\end{array}$ & $\begin{array}{l}\text { Percentage } \\
\text { similarity }\end{array}$ & Domain & Division & Class & Order & Family & Genus & Species \\
\hline \multirow{5}{*}{$\begin{array}{c}A B / 07 / 17 \\
-18 / C R S \\
91\end{array}$} & $K \gamma 118179.1$ & $99 \%$ & Fungi & Ascomycota & $\begin{array}{l}\text { Seccharo } \\
\text { mycetes }\end{array}$ & $\begin{array}{c}\text { Soccharom } \\
\text { yectoles }\end{array}$ & $\begin{array}{l}\text { Soccharom } \\
\text { ycetocreoe }\end{array}$ & Candida & tropicalis \\
\hline & KUB41838.1 & $99 \%$ & Fungi & Ascomycota & $\begin{array}{l}\text { Soccharo } \\
\text { mycetes }\end{array}$ & $\begin{array}{c}\text { Soccharom } \\
\text { ycetoles }\end{array}$ & $\begin{array}{l}\text { Saccharom } \\
\text { yectoceoe }\end{array}$ & Candida & tropicalis \\
\hline & KT236445.1 & $99 \%$ & Fungi & Ascomycota & $\begin{array}{c}\text { Soccharo } \\
\text { mycetes }\end{array}$ & $\begin{array}{c}\text { Soccharom } \\
\text { ycetoles }\end{array}$ & $\begin{array}{l}\text { Soccharom } \\
\text { ycetoceoe }\end{array}$ & Candida & tropicalis \\
\hline & KT229543.1 & $99 \%$ & Fungi & Ascomycota & $\begin{array}{l}\text { Soccharo } \\
\text { mycetes }\end{array}$ & $\begin{array}{c}\text { Soccharom } \\
\text { ycetales }\end{array}$ & $\begin{array}{l}\text { Saccharom } \\
\text { ycetocroe }\end{array}$ & Condida & tropicalis \\
\hline & 10008834.1 & $99 \%$ & Fungi & Ascomycoto & $\begin{array}{l}\text { Saccharo } \\
\text { mycetes }\end{array}$ & $\begin{array}{c}\text { Soccharom } \\
\text { ycetoles }\end{array}$ & $\begin{array}{l}\text { Soccharom } \\
\text { ycetoceose }\end{array}$ & Condida & tropicalis \\
\hline
\end{tabular}

b

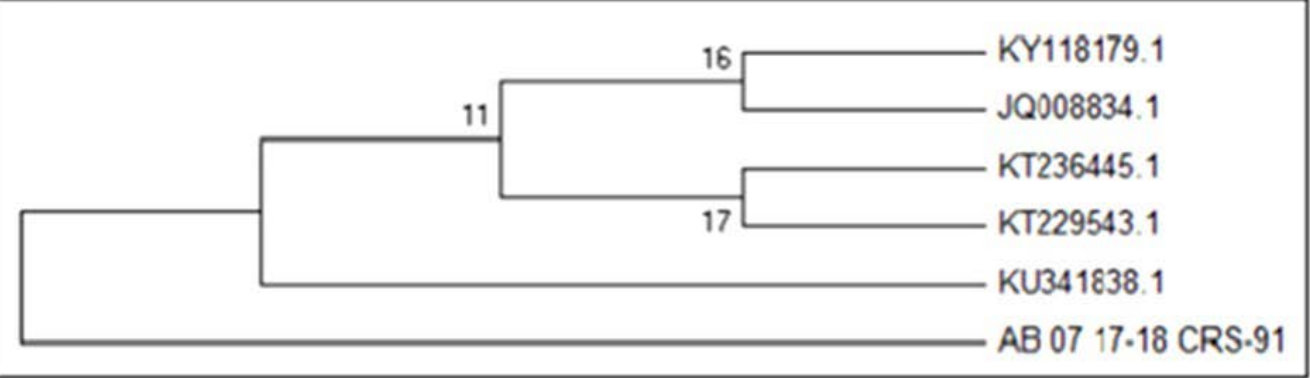

Fig. 1a-1b. Phylogenetic tree of Candida tropicalis RA1 and its related sequences retrieved from NCBI.

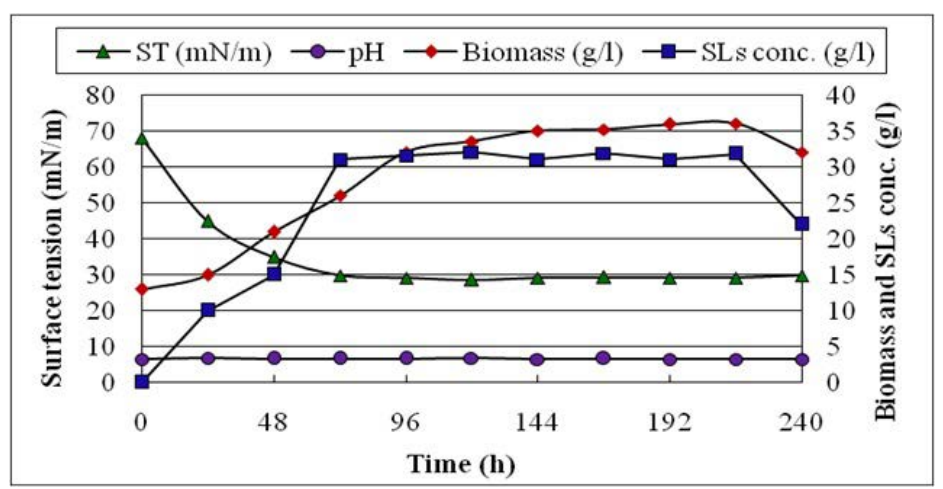

Fig. 2. Growth kinetics, pH, biomass production, and sophorolipid yield by Candida tropicalis RA1 using minimal salt medium $+2 \%$ soya oil $\left(w^{-1}\right)$, plotted as a function of time $(240 \mathrm{~h})$. 


\section{Surface tension measurement and critical micelle concentration}

The sophorolipid biosurfactant of up to $0.5 \%$ concentration decreased the ST from 72.2 $\mathrm{mN} \mathrm{m} \mathrm{m}^{-1}$ to $30 \mathrm{mN} \mathrm{m}^{-1}$ (Fig. 3).

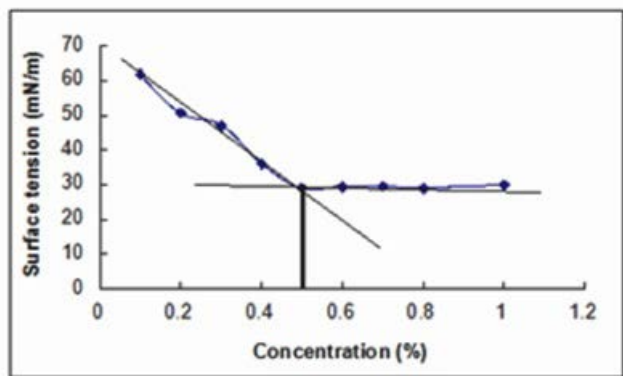

Fig. 3. Critical micelle concentration and minimum surface tension analysis of biosurfactant by $C$. tropicalis RA1.

\section{Emulsification index (E24)}

The sophorolipid biosurfactant generated stable emulsion with crude oil. It has showed E24 of $85 \%$, stable for $24 \mathrm{~h}$ (Fig. 4).

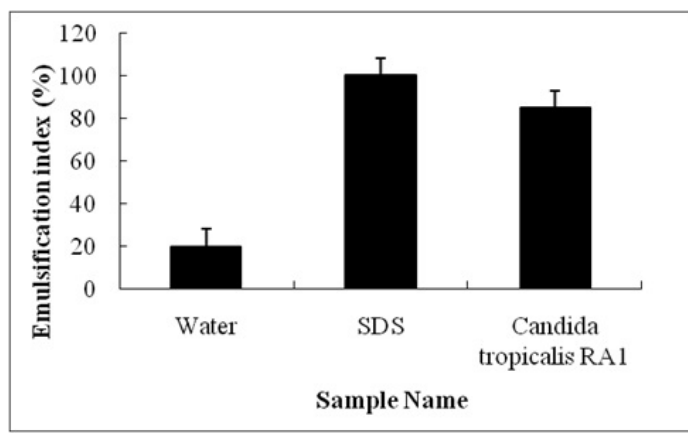

Fig. 4. Emulsification index analysis of $240 \mathrm{~h}$ fermented broth of Candida tropicalis RA1. The study includes $0.1 \%$ SDS and water used as a positive and negative control respectively.

\section{Stability study}

The stability evaluation of SLs is represented in Fig. 5a-5c. SLs demonstrated stable ST reduction while increase in $\mathrm{NaCl}$ concentration from $5-20 \%, \mathrm{pH}$ range of 2.0-10.0 and temperature range of $20^{\circ} \mathrm{C}$ to $121^{\circ} \mathrm{C}$.

Compositional analysis of biosurfactant Thin layer chromatography

Thin layer chromatography analysis of the SLs biosurfactant is represented in Fig. 6 .

Thin layer chromatogram revealed
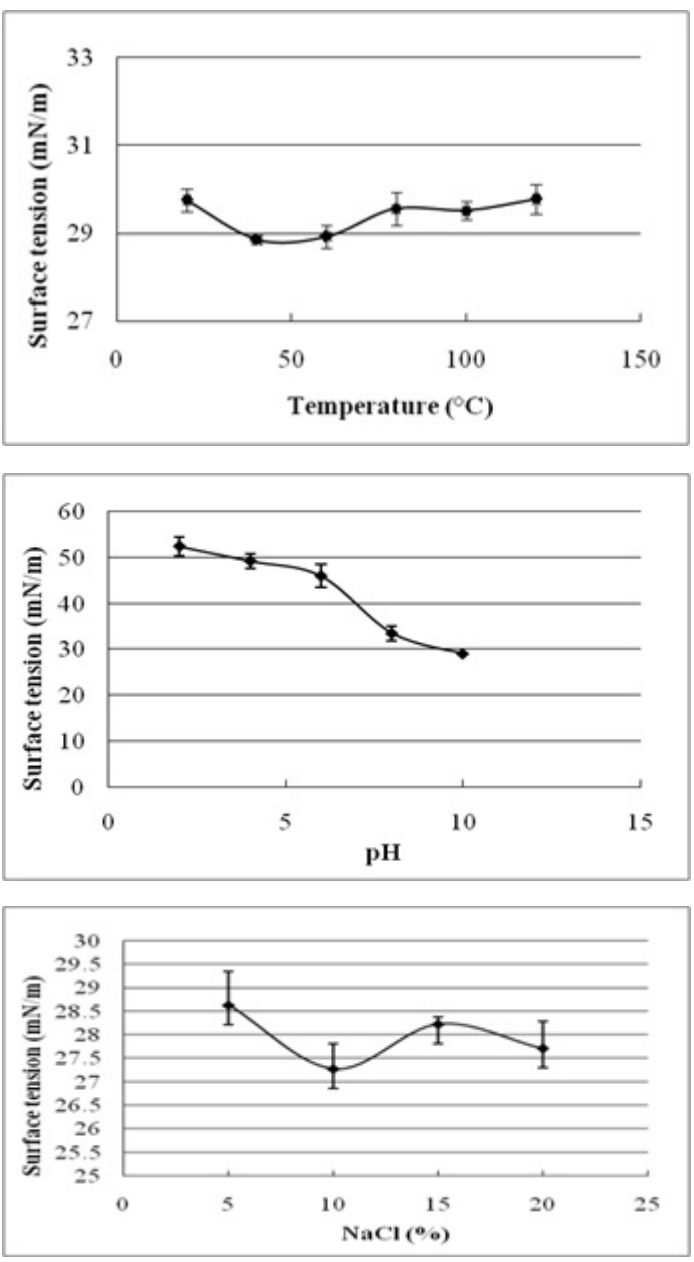

Fig. 5. Effect of (a) temperature $\left({ }^{\circ} \mathrm{C}\right)(\mathbf{b}) \mathrm{pH}$ and $(\mathbf{c})$ salinity (\%) on surface tension reduction. Error bars illustrate standard error of mean (SEM), calculated from two independent experiments run in triplicates.

'sophorolipid' nature of the biosurfactant. In addition, it was determined to be composed of lactonic form SLs (LS). The Rf values of the lactonic SLs were $0.48,0.58$, and 0.65 respectively.

Fourier transform infrared spectroscopy

The functional groups of biosurfactant were confirmed by FT-IR spectra of $C$. tropicalis RA1 as represented in Fig. 7 .

FT-IR analysis revealed that, heterogeneity evidenced by different characteristic peaks was in agreement with the possible presence of amino, carboxylic, hydroxyl and carbonyl groups. FT-IR spectrum peaks at $3009 \mathrm{~cm}^{-1}, 2922 \mathrm{~cm}^{-1}, 2854 \mathrm{~cm}^{-1}$ and $1744 \mathrm{~cm}^{-1}$ confirmed the presence of glycolipid biosurfactant. 


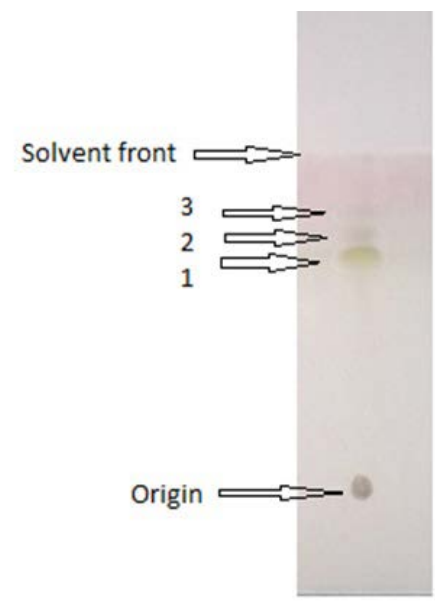

Fig. 6. Thin layer chromatogram showing separation sophorolipid components.

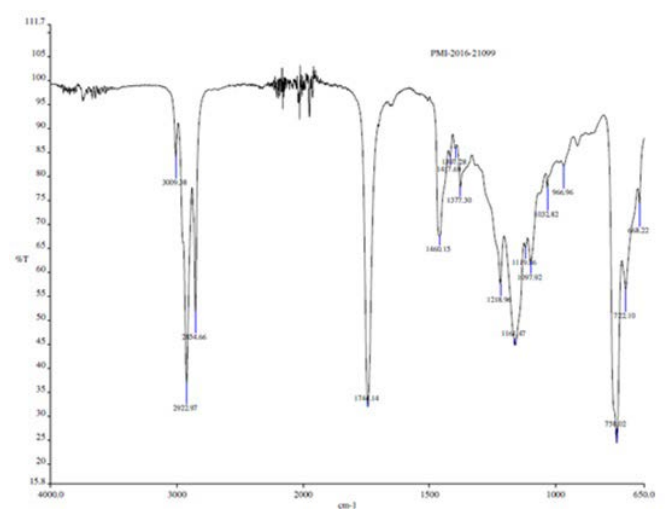

Fig. 7. Fourier transform infrared spectroscopy analysis of biosurfactant by Candida tropicalis RA1.
The FT-IR range of $C$. tropicalis RA1 had specific stretching vibration band of $-\mathrm{OH}$, throughout $3009.38 \mathrm{~cm}^{-1}$. The potent peaks at $2922.97 \mathrm{~cm}^{-1}$ and $2854.66 \mathrm{~cm}^{-1}$ were originated by the bending and stretching of $-\mathrm{CH}$ groups. Immersion around $2922.97 \mathrm{~cm}^{-1}$ and 2854.66 $\mathrm{cm}^{-1}$ is specified to the asymmetric $\mathrm{C}-\mathrm{H}$ stretch of $\mathrm{CH}_{2}$ and $\mathrm{CH}_{3}$ groups of aliphatic chains. Also, a weak symmetric stretching peak at $1741.14 \mathrm{~cm}^{-1}$ demonstrated the existence of ester carbonyl group $(\mathrm{C}=\mathrm{O}$ in $\mathrm{COOH})$ in the biosurfactant. The band at $1417.69 \mathrm{~cm}^{-1}$ and $1460.15 \mathrm{~cm}^{-1}$ be compatible to $\mathrm{C}-\mathrm{O}-\mathrm{H}$ in the plane binding of carboxylic acid $(-\mathrm{COOH})$. The ester carbonyl group was demonstrated by the band at $1377.30 \mathrm{~cm}^{-1}$ corresponding to $\mathrm{C}-\mathrm{O}$ deformation vibrations, although different groups were absorbed in this region. Absorption bands at $1218.96 \mathrm{~cm}^{-1}$ represents $\mathrm{O}-\mathrm{H}$ deformation. The peak at 1161.47 $\mathrm{cm}^{-1}, 1097.92 \mathrm{~cm}^{-1}, 1019.36 \mathrm{~cm}^{-1}, 1032.82 \mathrm{~cm}^{-1}$ and $966.96 \mathrm{~cm}^{-1}$ represent $\mathrm{C}-\mathrm{O}$ stretching and $\mathrm{CH}_{3}$ rocking.

Liquid chromatography-mass spectrometry

The LC-MS analysis of SLs biosurfactant was acquired in the positive mode (Fig. 8a.-8i.).

The present study reports nine forms of semi-purified SLs. Each eluting fragment of SLs had distinct MS chromatogram (8a-8i). The semipurified SLs had four AS and three LS homologues with C 18:1 unsaturated fatty acid chain. Nonacetylated $\mathrm{AS}$ was detected like $\left[\mathrm{M}+\mathrm{NH}_{4}\right]^{+}$,

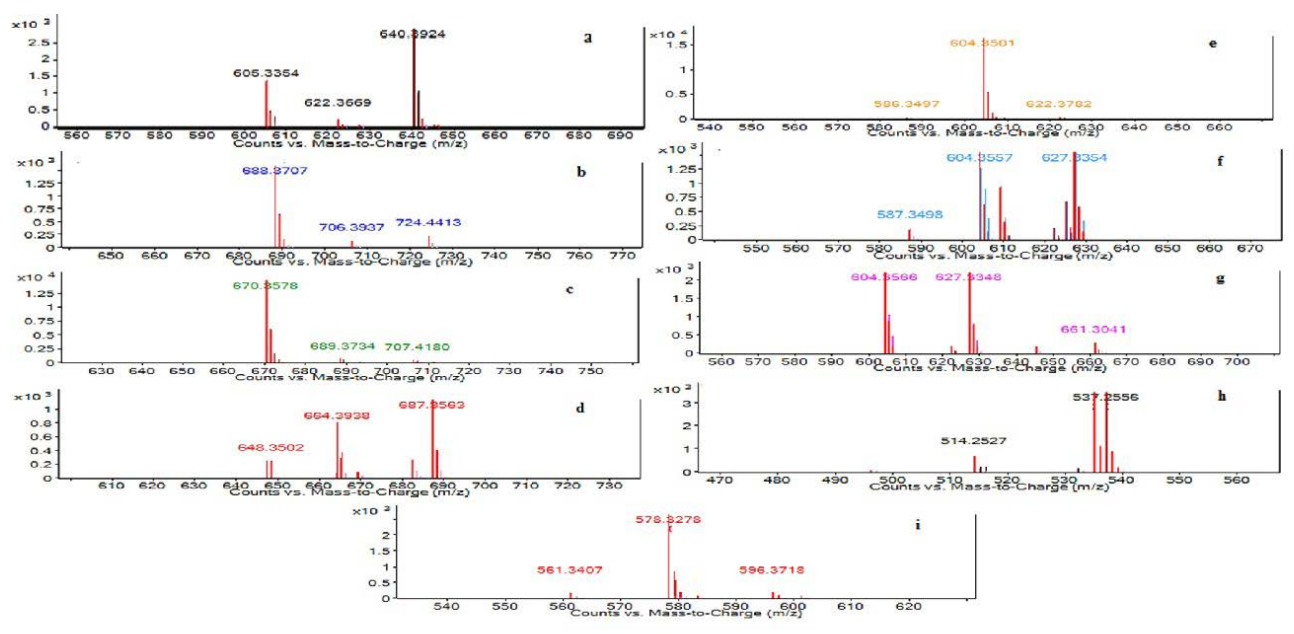

Fig. 8a-8i. LC-MS Characterization of sophorolipid by Candida tropicalis RA1 [LC-MS run in positive electrospray ionization mode $(+\mathrm{ESI})]$. 
$[\mathrm{M}+\mathrm{Na}]^{+}\left[-\mathrm{H}_{2} \mathrm{O}\right]$ at $\mathrm{m} / \mathrm{z} 640.39,627.33$ respectively. Additionally, $[\mathrm{M}+\mathrm{K}]+\left[-\mathrm{H}_{2} \mathrm{O}\right]$ unique non-acetylated AS was detected at $\mathrm{m} / \mathrm{z} 537.25$. The peak at $\mathrm{m} / \mathrm{z}$ 687.35 correspond to $[\mathrm{M}+\mathrm{Na}]^{+}$of mono-acetylated AS. $\mathrm{M}^{+}\left[-\mathrm{H}_{2} \mathrm{O}\right]$ and $\mathrm{M}^{+}\left[-\mathrm{H}_{2} \mathrm{O}\right]$ ions for di-acetylated AS were observed at $\mathrm{m} / \mathrm{z} 688.37$ and 670.35 respectively. Non-acetylated LS were detected with sum of three ions such as $[\mathrm{M}+\mathrm{Na}]^{+}\left[-\mathrm{H}_{2} \mathrm{O}\right]$ at $\mathrm{m} / \mathrm{z} 609.32$ and two $\mathrm{M}^{+}$ions at $\mathrm{m} / \mathrm{z} 604.35$ and 578.32 respectively. Table 1 represents complete list of SLs homologues detected in C. tropicalis RA1. Antibacterial activity

The antibacterial activity of semipurified SLs evaluated against human pathogens; Escherichia coli, Listeria monocytogenes, and Staphylococcus aureus is presented in Table 2.

Table 1. The chemical formula, molecular mass, and structural features of sophorolipid homologues by Candida tropicalis RA1 determined using LC-MS

\begin{tabular}{|c|c|c|c|}
\hline Structural Features & Formula & $\begin{array}{l}\text { Molecular } \\
\text { Mass }\end{array}$ & $\begin{array}{c}\text { Sophorolipid } \\
\text { Type }\end{array}$ \\
\hline Non-acetylated acidic SL fatty acid $C_{18: 1}$ & $\mathrm{C}_{30} \mathrm{H}_{54} \mathrm{O}_{13}$ & 622.35 & Acidic \\
\hline Di-acetylated acidic SL fatty acid $C_{18: 1}$ & $\mathrm{C}_{34} \mathrm{H}_{58} \mathrm{O}_{15}$ & 706.38 & Acidic \\
\hline Di-acetylated acidic SL fatty acid $C_{18: 1}$ & $\mathrm{C}_{34} \mathrm{H}_{56} \mathrm{O}_{14}$ & 688.36 & Acidic \\
\hline Mono-acetylated acidic SL fatty acid $\mathrm{C}_{18: 1}$ & $\mathrm{C}_{32} \mathrm{H}_{56} \mathrm{O}_{14}$ & 664.36 & Acidic \\
\hline Non-acetylated lactonic SL fatty acid $C_{18: 1}$ & $\mathrm{C}_{30} \mathrm{H}_{52} \mathrm{O}_{12}$ & 604.35 & Lactonic \\
\hline Non-acetylated lactonic SL fatty acid $C_{18: 1}$ & $\mathrm{C}_{30} \mathrm{H}_{52} \mathrm{O}_{12}$ & 604.35 & Lactonic \\
\hline Non-acetylated acidic SL fatty acid $C_{18: 1}$ & $\mathrm{C}_{30} \mathrm{H}_{54} \mathrm{O}_{13}$ & 622.36 & Acidic \\
\hline Non-acetylated acidic SL fatty acid $C_{11}$ & $\mathrm{C}_{22} \mathrm{H}_{42} \mathrm{O}_{13}$ & 514.26 & Acidic \\
\hline Non-acetylated lactonic SL fatty acid $\mathrm{C}_{16}$ & $\mathrm{C}_{28} \mathrm{H}_{50} \mathrm{O}_{12}$ & 578.33 & Lactonic \\
\hline
\end{tabular}
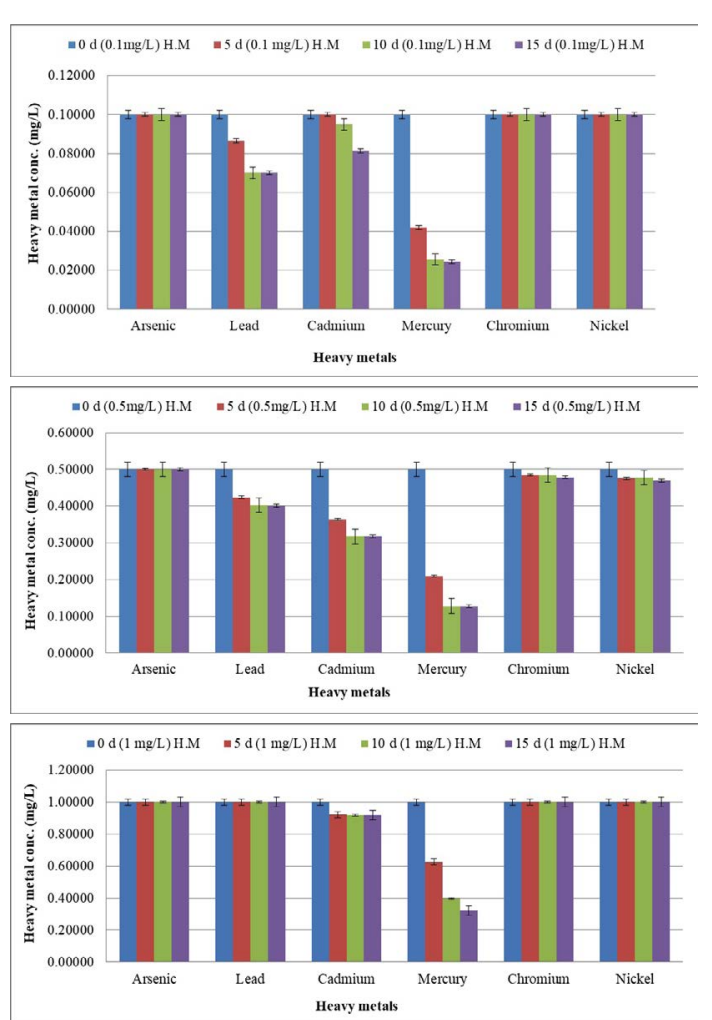

Fig. 9. Heavy metal ion biosorption by Candida tropicalis RA1 using (a) $0.1 \mathrm{mg} \mathrm{l}^{-1}$ (b) $0.5 \mathrm{mg} \mathrm{l}^{-1}$ and (c) $1.0 \mathrm{mg} \mathrm{l}^{-1}$ concentration of heavy metal ions.
Table 2. Antibacterial activity of sophorolipid by Candida tropicalis RA1 against human pathogens

\begin{tabular}{lc}
\hline Human Pathogens* & $\begin{array}{c}\text { Minimum Inhibitory } \\
\text { Concen. }\left(\mu \mathrm{g} \mathrm{m}^{-1}\right)\end{array}$ \\
\hline Escherichia coli & 1000 \\
Listeria monocytogenes & 500 \\
Staphylococcus aureus & 250 \\
Staphylococcus aureus & 250
\end{tabular}

*Human pathogens collection resource: Escherichia coli: ATCC 35218, Listeria monocytogenes: ATCC 19115, Staphylococcus aureus: NCIM 5345 and Staphylococcus aureus: NCIM 2079.

The minimum inhibitory concentration (MIC) was determined therein.

The SLS was highly effective against $S$. aureus (NCIM 5345, 2079) followed by E. coli (ATCC 35218), and L. monocytogenes (ATCC 19115) respectively.

\section{Heavy metal ions biosorption}

The biosorption efficacy of $C$. tropicalis RA1 against $0.10 \mathrm{mg} \mathrm{l}^{-1}, 0.5 \mathrm{mg} \mathrm{l}^{-1}$, and $1.0 \mathrm{mg} \mathrm{l}^{-1}$ concentration of arsenic, lead, cadmium, mercury, chromium, and nickel is represented in Fig. 9a-9c. Highest heavy metal reduction was observed for mercury from 58 to $74 \%$ until d15, at $0.1 \mathrm{mg} \mathrm{l}^{-1}$ and $0.5 \mathrm{mg} \mathrm{l}^{-1}$ concentrations respectively. 
The mercury with $1.0 \mathrm{mg} \mathrm{l}^{-1}$ concentration was reduced up to $67 \%$ on d15.

Beside this, lead in $0.1 \mathrm{mg} \mathrm{l}^{-1}$ concentration had $13 \%$ reduction in $d 5$, was noted with $29 \%$ decrease until d15. The reduction trend was slowed down at $0.5 \mathrm{mgl}^{-1}$, to $19 \%$. Further, no lead reduction was observed at $1.0 \mathrm{mg} \mathrm{l}^{-1}$.

The cadmium in $0.5 \mathrm{mg} \mathrm{l}^{-1}$ was reduced up to $36 \%$ until d15. Its further reduction was slowed down to $8 \%$ at $1.0 \mathrm{mgl}^{-1}$ concentration. There was no change in percent reduction of cadmium and mercury at $0.1 \mathrm{mg} \mathrm{l}^{-1}, 0.5 \mathrm{mg} \mathrm{l}^{-1}$, and $1.0 \mathrm{mg} \mathrm{l}^{-1}$ concentrations. The similar observation was noted for lead at $0.1 \mathrm{mg} \mathrm{l}^{-1}$ and $0.5 \mathrm{mg} \mathrm{l}^{-1}$ concentrations respectively. Nonetheless; $0.1 \mathrm{mg} \mathrm{l}^{-1}$ chromium and nickel were reduced by $4 \%$ and $6 \%$ therein.

\section{DISCUSSION}

The present research is aimed at screening of novel SLs biosurfactant producing microorganisms. It was followed by physicochemical characterisation, biomedical, and bioremediation application studies. The microbial cultivation using water immiscible hydrocarbons supports biosurfactant production ${ }^{19}$. In this context, some of the highlighted references are of Dhail et al. ${ }^{20}$ and Sneha et al. ${ }^{21}$. They have preferred oil reserviors; oil spilled marine water, and marine sediments for isolation of biosurfactant producing microorganisms. In fulfillment of our research objectives, oil contaminated refinery soil has been selected as a sampling source. Since oil is crucial element for the growth of biosurfactant producing microorganisms, most efficient strains can be isolated using oil contaminated refinery soil. The microbes acclimatize well to the high concentration of oil being used as a sole carbon source. In this context, yeast strain RA1 isolated from oil contaminated refinery soil exhibited promising activities in primary screening towards SLs biosurfactant production.

Since E24 determination and drop collapse test belong to selective methods ${ }^{22}$, promising activity in drop collapse test and $85 \%$ E24 against crude oil marks unique properties of the SLs. Morikawa et al. ${ }^{23}$ reported direct proportion between zone of clearance and the concentration of surface active agent. In this view, oil displacement of $32.2 \mathrm{~mm}^{2}$ stands out efficacy of the SLs. According to Banat et al. ${ }^{24}$, microbes can decrease the ST to $35 \mathrm{mN} \mathrm{m}^{-1}$. The present study reports ST reduction from $68.8 \mathrm{mN} \mathrm{m}^{-1}$ to $29.9 \mathrm{mN}$ $\mathrm{m}^{-1}$ suggesting SLs efficacy.

The strains displaying short lag phase can be considered for SLs biosurfactant production. Inversely, some strains represent long lag phase and biosurfactant production at late log phase or stationary phase ${ }^{25}$. The current study reports a short lag phase while yeast growth and exhibited an exponential phase until $144 \mathrm{~h}$. However, maximal cell biomass production occurred during the stationary phase. The statistically significant difference between SLS yield and yeast growth phase, suggests about growth associated kinetics. Since yeast strains have different mechanisms behind SLs production, the interrelationship varies.

It suggests that, SLs is produced as primary metabolite accompanying cellular biomass increase ${ }^{26}$ with effective production under thermostat conditions ${ }^{27}$. Also, decrease in ST from $68 \mathrm{mN} \mathrm{m}^{-1}$ to $29.9 \mathrm{mN} \mathrm{m}^{-1}$ represents $3.21 \times 10^{10} \mathrm{CFU} \mathrm{m^{-1 }}$ that remained stable until $240 \mathrm{~h}$. This is in agreement with Accorsini et al. ${ }^{28}$ where, exponentially growing cells of Candida antarctica exhibited greatest ST reduction. Similarly, Rufino et al. ${ }^{29}$ and Sobrinho et al. ${ }^{30}$ reported highest ST reduction during exponential growth phase of Candida lipolytica and Candida sphaerica. However, Rufino et al. ${ }^{13}$ stated direct proportion between biosurfactant and biomass, having inverse proportion to ST. Previous research conducted by Amezcua-Veja et al. ${ }^{31}$ had similar observations for biosurfactant production and ST reduction by Candida ingens. This indicates that; biosurfactant production and ST reduction are not cell growth associated. No significant change in $\mathrm{pH}$ was observed during experiment which is in accordance with Luna et al. ${ }^{32}$.

Previous researches report that; SLs yield differs according to the type of substrate used. Accorsini et al. ${ }^{28}$ reported highest decrease in ST, using $6 \%$ soya oil and glutamic acid substrates. Rufino et al. ${ }^{29}$ and Sobrinho et al. ${ }^{30}$ reported $4.5 \mathrm{~g}$ $S \mathrm{SS}^{-1}$ using secondary carbon source. The present study represents $35 \mathrm{~g} \mathrm{SLs} \mathrm{I}^{-1}$ using $2 \%$ soya oil, exemplyfying the efficacy.

Critical micelle concentration is one of the integral properties of the SLs. The current research reports decrease in ST from $72.2 \mathrm{mN} \mathrm{m}^{-1}$ to 30 $\mathrm{mN} \mathrm{m}^{-1}$, by increasing the SLs concentration up to 
0.5\%. A lower CMC represents high efficiency of the surfactant ${ }^{33}$. Accorsini et al. ${ }^{28}$ reported $130 \mathrm{mg}$ $\mathrm{I}^{-1}$ (CMC) and $39 \mathrm{mN} \mathrm{m}^{-1}$ (ST) for a mixture of SLS produced by $C$. bombicola. Sen et al. ${ }^{10}$ reported similar CMC for SLs biosurfactant by Rhodotorula babjevae YS3. Daylin et al. ${ }^{8}$ reported decrease in ST from $70 \mathrm{mN} \mathrm{m}^{-1}$ to $28.8 \mathrm{mN} \mathrm{m}^{-1}$; at CMC concentration of $1.5 \%$ in C. tropicalis UCP 1613. The $\mathrm{CMC}$ varies in different strains due to nature of the acyl chain and open-chain or lactone form. Price et al. ${ }^{34}$ reported CMCs of $5.6 \mathrm{mg} \mathrm{l}^{-1}$ and $6.9 \mathrm{mg} \mathrm{l}^{-1}$ for $S$. bombicola sophorolipids; 60, 600-diO-acetyl-b-D-Glcp-21-O-b-D-Glcp-17hydroxystearate 1,40 -lactone and 60, 600-di-Oacetyl-b-D-Glcp-21-O-b-D-Glcp-17-hydroxyoleate $1,40-$ lactone. Also, the novel anionic, open-chain sophorolipid 60, 600-di-O-acetyl-b-D-Glcp-21 -O-b-D-Glcp-18-hydroxyoleic from Candida $s p$. NRRL Y-27208 had CMC of $46.4 \mathrm{mg} \mathrm{l}^{-1}$. The current study reports three lactonic and six open chain SLS forms (Table 1), may have association with $0.5 \%$ CMC.

Sen et al. ${ }^{10}$ reported stable emulsion of R. babjevae YS3 SLs until 168 h, with E24 of $98 \%$. The current study reports stable emulsion until 24 h with E24 of $85 \%$.

In addition, biosurfactant stability under extreme environmental conditions is an important parameter of evaluation ${ }^{10}$. The present study reports excellent stability of SLS for $\mathrm{pH}$, temperature, and salinity. It indicates their efficacy in bioremediation and oil recovery applications. Biosurfactant stability plays vital role in commercial and field applications. The current research reports ST reducing ability of SLs at $5-20 \% \mathrm{NaCl}$, indicating their application in marine environments. Luna et al. ${ }^{32}$ reported stable ST reduction and emulsification ability of biosurfactant by Candida sphaeria UCP0995 under extreme $\mathrm{pH}$, temperature, and salinity. We report excellent ST reduction by SLs under extreme $\mathrm{pH}$ and temperature range of $2-10$ and $20^{\circ} \mathrm{C}$ to $121^{\circ} \mathrm{C}$.

Moreover, TLC analysis revealed the lactonic composition SLs. Sen et al. ${ }^{10}$ reported AS and LS forms representing Rf values of $0.49,0.56$, and 0.68 . They do correspond with Rf values of the present study $(0.48,0.58$, and 0.65$)$. Fig. 6 chromatogram revealed 'sophorolipid' nature of the biosurfactant based on ${ }^{35,36}$.

The FT-IR range reveals the heterogeneity as evidenced by different characteristic peaks, representing the presence of amino, carboxylic, hydroxyl, and carbonyl group; the spectral observations were in alignment with research reports ${ }^{37,38,39}$. Similarly, the mass spectral ions from LC-MS analysis were determined using previous research ${ }^{35}$.

The biosurfactants demonstrate the antimicrobial properties; thus can replace the antibiotics that are plaguing the world today. Biosurfactants may exhibits antagonism through cellular membrane destabilization. It leads to cell rupture. Previous research demonstrated antibacterial activity of biosurfactant against Candida sp. ${ }^{40}$ and Pseudomonas sp. ${ }^{41}$. Morya et $a l .^{42}$ and Shah et $a l .^{43}$ reported that, antimicrobial activity of SLs biosurfactant varies with production media composition. We report the antimicrobial activity of SLs produced using $2 \%$ soya oil against E. coli, S. aureus and L. monocytogenes.

Fundamentally, SLs homologues may vary in different media, resulting into varying effects against pathogens ${ }^{44}$. The microbes including; Bacillus subtilis, Magnetospirillum gryphiswaldense, Rhizopus arrhizus, Saccharomyces cerevisiae, and Chaeto-morphalinum have been reported as potential biosorbents ${ }^{45,46}$. Candida $s p$. is one of the most widely studied yeast for biosorption performance ${ }^{47}$. The current study reports $74 \%$ mercury reduction until d15 at $0.1 \mathrm{mg} \mathrm{l}^{-1}$ and $0.5 \mathrm{mg} \mathrm{l}^{-1}$. Further, $67 \%$ mercury reduction was reported at $1.0 \mathrm{mg} \mathrm{l}^{-1}$ concentration therein. The $\mathrm{MCL}$ guidelines ${ }^{17}$ reported $0.00003 \mathrm{mg} \mathrm{l}^{-1}$ to be an acceptable limit for mercury. This remarkable mercury reduction demands comprehensive research.

Beside this, decreasing trend of lead reduction was observed with increase in concentration from $0.1 \mathrm{mg} \mathrm{l}^{-1}$ to $0.5 \mathrm{mg} \mathrm{l}^{-1}$. Lead reduction was not observed at $1.0 \mathrm{mg}$ $\mathrm{I}^{-1}$ concentration describing the MIC therein. Nonetheless, cadmium reduction was slowed down with increase in concentration from $0.5 \mathrm{mg}$ $\mathrm{I}^{-1}$ to $1.0 \mathrm{mg} \mathrm{l}^{-1}$.

The present study reports uniform \% reduction of lead, cadmium, and mercury at 0.1 $\mathrm{mg} \mathrm{l}^{-1}, 0.5 \mathrm{mg} \mathrm{l}^{-1}$ and $1.0 \mathrm{mg} \mathrm{l}^{-1}$ concentrations, on $\mathrm{d} 10$ and $\mathrm{d} 15$. The similar observation was noted for lead at $0.1 \mathrm{mg} \mathrm{l}^{-1}$ and $0.5 \mathrm{mg} \mathrm{l}^{-1}$, suggesting the establishment of equilibrium phase. The current 
research remarks heavy metal biosorption efficacy of $C$. tropicalis RA1 in polluted water or land sites.

\section{CONCLUSIONS}

In conclusion; the present research states that, oil refinery area can be one of the dynamic sources for isolation of most efficient biosurfactant producing microorganisms. To our knowledge, this is the first report wherein, $C$. tropicalis RA1 is recorded with nine distinct forms of SLs. The batch fermentation yields of $31 \mathrm{~g} \mathrm{SLs} \mathrm{I}^{-1}$ with short lag phase state its efficacy. The growth associated kinetics report the SLs production as primary metabolites. In addition, excellent antibacterial activity of SLs highlights its distinct advantage in the biomedical field. The biosorption efficacy of $C$. tropicalis RA1 against heavy metals, beyond $\mathrm{MCL}$ standards recommend the application in polluted sites.

\section{ACKNOWLEDGMENTS}

$R$ A is grateful to the Praj Matrix R \& D Center, Division of Praj Industries Ltd, Pune; Maharashtra, India for supporting the research work conducted at Praj Matrix.

\section{CONFLICT OF INTEREST}

The authors declare that they have no conflict of interest.

\section{FUNDING}

None.

\section{AUTHOR CONTRIBUTIONS}

RA collected the samples, conducted the research, analysed data and prepared the manuscript. MC guided the entire research and manuscript preparation.

\section{DATA AVAILABILITY}

All datasets generated or analyzed during this study are included in the manuscript and can also be obtained from the corresponding author on reasonable request.

\section{ETHICS STATEMENT}

This article does not contain any studies with human participants or animals performed by any of the authors.

\section{REFERENCES}

1. Wu, Y.S., Ngai, S.C., Goh, B.H., Chan K.G., Lee L.H., Chuah, L.H. Anticancer activities of surfactin and potential application of nanotechnology assisted surfactin delivery. Front. Pharmacol., 2017; 8: 761. https://doi.org/10.3389/fphar.2017.00761

2. Sarubbo, L.A., Junior, R.B., Luna, J.M., Rufino, R.D., Santos, V.A., Banat, I.M. Some aspects of heavy metals contamination remediation and role of biosurfactants. Chem. Ecol., 2015; 31: 707-723. https://doi.org/10.1080/02757540.2015.1095293

3. Rispoli, F.J., Badia, D., Shah, V. Optimization of the fermentation media for SLs production from Candida bombicola ATCC 22214 using a simplex centroid design. Biotechnol. Prog., 2010; 26: 938-944. https://doi. org/10.1002/btpr.399

4. Shao, L., Song, X., Ma, X. Bioactivities of SLs with different structures against human esophageal cancer cells. J. Surg. Res., 2012; 173: 286-291. https://doi. org/10.1016/j.jss.2010.09.013

5. Cavalero, D.A., Cooper, D.G. The effect of medium composition on the structure and physical state of SLs by Candida bombicola ATCC 22214. J. Biotechnol., 2003; 103: 31-41. https://doi.org/10.1016/S01681656(03)00067-1

6. Chandran, P. and Das, N. Biosurfactant production and diesel oil degradation by yeast species Trichosporon asahii isolated from petroleum hydrocarbon contaminated. Int. J. Eng. Sci. Technol., 2010; 2: 69426953.

7. Almeida, D.G., Silva, S.F., Luna, J.M. Rufino, R.D., Santos V.A., Sarubbo, L.A. Response surface methodology for optimizing the production of biosurfactant by Candida tropicalis on industrial waste substrates. Front. Microbiol., 2017; 8: 1-13. https://doi.org/10.3389/ fmicb.2017.00157

8. Daylin, R.R., Rosieide, F. da. S. A., Goretti, S. Da. S., Rodrigo, A. De. H., Milagre, A.P., Paricia, N., Jose, C. V. J., Maria, A. De. R.S., Campos, T.G.M. Promising biosurfactant produced by a new Candida tropicalis UCP 1613 strain using substrates from renewable-resources. African J. Microbiol. Res., 2017; 11(23): 981-991. https://doi. org/10.5897/AJMR2017.8486

9. Gumel, A.M., Annuar, M.S., Chisti, Y. Recent advances in the production, recovery and applications of polyhydroxyalkonates. J. Polym. Environ., 2013; 21: 580-605. https://doi.org/10.1007/s10924-012-0527-1

10. Sen, S., Borah, S.N., Bora, A., Deka, S. Production, characterization, and antifungal activity of biosurfactant produced by Rhodotorula babjevae YS3. Microbial Cell Factories, 2017; 16: 1-14. https:// doi.org/10.1186/s12934-017-0711-z

11. Nunez, A., Ashby, R., Foglia, T.A., Solaiman D. K.Y. Analysis and characterization of sophorolipids by liquid chromatography with atmospheric pressure chemical ionization. Chromatographia, 2001; 53: 673-677. https://doi.org/10.1007/BF02493019

12. Smyth, T.P., Perfumo, A., Marchant, R., Banat, I.M. Isolation and analysis of low molecular weight microbial glycolipids. Handbook of Hydrocarbon and Lipid Microbiology, 2010; 3705-3723. https://doi. 
org/10.1007/978-3-540-77587-4_291

13. Rufino, R.D., Luna, J. M., Campos Takaki, G.M., Sarubbo L.A. Characterization and properties of $\quad \mathrm{t} \mathrm{h} e$ biosurfactant produced by Candida lipolytica UCP 0988. Electron J. Biotechnol., 2014; 17: 1-5. https:// doi.org/10.1016/j.ejbt.2013.12.006

14. Cooper, D.G., Goldenberg, B.G. Surface-active agents from two Bacillus Species. Appl. Environ. Microbiol., 1987; 53: 224-229.

15. Imura, T., Kawamura, D., Morita, T., Sato, S., Fukuoka, T. Yosuke, Y., Takahashi, M., Wada, K., Kitamoto, D. Production of sophorolipids from non-edible Jatropha oil by Stamerella bombicola NBRC 10243 and evaluation of their interfacial properties. J. Oleo. Sci., 2013; 62: 857-864. https://doi.org/10.5650/ jos.62.857

16. Samad, A., Zhang, J., Chen, D., Liang, Y. Sophorolipid production from bio-mass hydrolysates. Appl. Biochem. Biotechnol., 2015; 175: 2246-57. https:// doi.org/10.1007/s12010-014-1425-x

17. Babel, S., Kurniawan, T.A. Low-cost adsorbents for heavy metals uptake from contaminated water: A review. J. Hazard Mater, 2003; 97: 219-243. https:// doi.org/10.1016/S0304-3894(02)00263-7

18. Ibrahim, W.M., Hassan, A.F., Azab, Y.A. Biosorption of toxic heavy metals from aqueous solution by ulva lactuca activated carbon. Egypt J. Basic. Appl. Sci., 2016; 3: 241-249. https://doi.org/10.1016/j. ejbas.2016.07.005

19. Almeida, D.G., Silva, S.F., Luna, J.M., Rufino, R.D., Santos, V.A., Banat, I.M., Sarubbo, L.A. Biosurfactants: promising molecules for petroleum biotechnology advances. Front. Microbiol., 2016; 7: 1718. https:// doi.org/10.3389/fmicb.2016.01718

20. Dhail, S. Isolation of potent biosurfactant producing bacteria from oil spilled marine water and marine sediments. Afr. J. Biotechnol, 2012; 11:16751-16757.

21. Sneha, K.S., Padmapriya, B., Rajeshwari, T. Isolation and Screening of Biosurfactants produced by Pseudomonas aeruginosa from oil spilled soils. Int. J. Pharm. Biol. Sci. Arch., 2012; 3:321-325.

22. Nayarisseri, A., Singh, P., Singh, S.K. Screening, isolation and characterization of biosurfactant producing Bacillus subtilis strain ANSKLAB03. Bioinformation, 2018; 14(6): 304-314. https://doi.org/10.6026/97320630014304

23. Morikawa, M., Hiratr, Y., Imanaka, T.A. Study on the structure- function relationship of lipopeptide biosurfactants. Biochem. Biophys. Acta., 2000; 1488 (3): 211-218. https://doi.org/10.1016/S13881981(00)00124-4

24. Banat, I.M. Biosurfactants production and possible uses in microbial enhanced oil recovery and oil pollution remediation/: A Review. Bioresour. Technol., 2014; 51: 1-12. https://doi.org/10.1016/09608524(94)00101-6

25. Sobrinho, H.B. de. S., Luna, J.M., Rufino, R.D., Porto, A.L.F., Sarubbo L.A. Assessment of toxicity of a biosurfactant from Candida sphaerica UCP 0995 cultivated with industrial residues in a bioreactor. Electron J. Biotechnol., 2013; 16(4). https://doi. org/10.2225/vol16-issue4-fulltext-4

26. Abouseoud, M., Maachi, R., Amrane, A. Biosurfactant production from olive oil by Pseudomonas fluorescens. Trends Microbiol., 2007; 340-347.

27. Klein, J., and Wagner, F. Different Strategies to optimize the production phase of immobilized cells. Ann. N.Y. Acad. Sci., 1987; 501: 306-316. https://doi. org/10.1111/j.1749-6632.1987.tb45728.x

28. Accorsini, F.R., Mutton, M.J.R., Lemos, E.G., Benincasa, M. Biosurfactants production by yeasts using soybean oil and glycerol as low cost substrate. Braz. J. Microbiol., 2012; 43: 116-125. https://doi. org/10.1590/S1517-83822012000100013

29. Rufino, R.D., Sarubbo, L.A., Campos-Takaki, G.M. Enhancement of stability of biosurfactant produced by Candida lipolytica using industrial residue as substrate. World J. Microbiol. Biotechnol., 2007; 23: 729-734. https://doi.org/10.1007/s11274-006-9278-2

30. Sobrinho, H.B.S., Rufino, R.D., Luna, J.M., Salgueiro, A.A., Campos-Takaki, G.M., Leite L.F.C., Sarubbo, L.L. Utilization of two agro industrial by-products for the production of a surfactant by Candida sphaerica UCP0995. Process Biochem., 2008; 43: 912-917. https://doi.org/10.1016/j.procbio.2008.04.013

31. Amezcua, V.C., Poggi, V.H.M., Esparza, G.F., Rodriguez, V.R. Effect of culture condition on fatty acids composition of a biosurfactant produced by Candida ingens and changes of surface tension of culture media. Bioresour. Technol., 2007; 98: 237-240. https:// doi.org/10.1016/j.biortech.2005.11.025

32. Luna, J.M., Rufino, R.D., Sarubbo, L.A., CamposTakaki, G.M. Characterization, surface properties and biological activity of a biosurfactant produced from industrial waste by Candida sphaerica UCP0995 for application in the petroleum industry. Colloids Surf. B. Biointerfaces, 2013; 102: 202-209. https://doi. org/10.1016/j.colsurfb.2012.08.008

33. Pacwa-P ${ }^{3}$ ociniczak, M., $P^{3}$ aza, G.A., Piotrowska-Seget, Z., Cameotra, S.S. Environmental applications of biosurfactants: Recent advances. Int. J. Mol. Sci., 2011; 12: 633-654. https://doi.org/10.3390/ijms12010633

34. Price, N.P.J., Ray, K.J., Vermillion, K.E., Dunlap, C.A., Kurtzman, C.P. Structural characterization of novel sophorolipid biosurfactants from a newly identified species of Candida yeast. Carbohydr. Res., 2012; 348: 33-41. https://doi.org/10.1016/j.carres.2011.07.016

35. Asmer, H.J., Lang, S., Wagner, F., Victory, W. Microbial production, structure elucidation and bio-conversion of sophorose lipids. J. Am. Oil Chem., 1988; 65: 1460-1466. https://doi.org/10.1007/BF02898308

36. Ribeiro, I.A., Bronze, M.R., Castro, M.F., Ribeiro, M.H. Optimization and correlation of HPLC-ELSD and HPLCMS/MS methods for identification and characterization of sophorolipids. J. Chromatogr. B. Analyt. Technol. Biomed. Life Sci., 2012 899: 72-80. https://doi. org/10.1016/j.jchromb.2012.04.037

37. Bajaj, V., Tilay, A., Annapure, U. Enhanced production of bioactive sophorolipids by Starmerella bombicola NRRL Y-17069 by design of experiment approach with successive purification and characterization. J. Oleo. Sci., 2012; 61: 377-386. https://doi.org/10.5650/ jos.61.377

38. Hu, Y., and Ju, L. Sophorolipid production from different lipid precursors. Enzyme Microb. Technol., 
2001; 29: 593-601. https://doi.org/10.1016/S01410229(01)00439-2

39. Ilori, M.O., Amobi, C.J., Odocha, A.C. Factor's affecting biosurfactant production by oil degrading Aeromonas spp. isolated from a tropical environment. Chemosphere, 2005; 61: 985-992. https://doi. org/10.1016/j.chemosphere.2005.03.066

40. $\quad$ Arutchelvi, J.I., Bhaduri, S., Uppara, P.V., Doble, M. Mannosylerythritol lipids: A review. J. Ind. Microbiol. Biotechnol., 2008; 35: 1559-1570. https://doi. org/10.1007/s10295-008-0460-4

41. Benincasa, M., Abalos, A., Oliveira, I., Manresa, A. Chemical structure, surface properties and biological activities of the biosurfactant produced by Pseudomonas aeruginosa LBI from soapstock. Antonie van Leeuwenhoek, 2004; 85: 1-8. https://doi. org/10.1023/B:ANTO.0000020148.45523.41

42. Morya, V.K., Park, J. ho., Kim, T.J., Jeon, S., Kim, E.K. Production and characterization of low molecular weight sophorolipid under fed-batch culture. Bioresour. Technol., 2013; 143: 282-288. https://doi. org/10.1016/j.biortech.2013.05.094

43. Shah, V., Badia, D., Ratsep, P. Sophorolipids having enhanced antibacterial activity. Antimicrob. Agents Chemother., 2007; 51: 397-400. https://doi. org/10.1128/AAC.01118-06

44. Joutey, N.T., Sayel, H., Bahafid, W., Ghachtouli N. Mechanisms of hexavalent chromium resistance and removal by microorganisms. Rev. Environ. Contam. Toxicol., 2015; 233: 45-69. https://doi. org/10.1007/978-3-319-10479-9_2

45. Romera, E., Gonzalez, F., Ballester, A., Blazquez, M.L., Munoz, J.A. Biosorption with algae: A statistical review. Crit. Rev. Biotechnol., 2006; 26: 223-235. https://doi.org/10.1080/07388550600972153

46. Vijayaraghavan, K., Yan, Y.S. Bacterial Biosorbents and Biosorption. Biotchnol. Adv., 2008; 26(3): 266-91. https://doi.org/10.1016/j.biotechadv.2008.02.002 